Preventive practices of cancer screening in women: comparison of estimates from ISA - Capital survey and the telephonebased Surveillance of Risk and Protective Factors for Chronic Diseases (VIGITEL - São Paulo)

\section{Práticas preventivas de detecção de câncer em mulheres: comparação das estimativas dos inquéritos de saúde (ISA - Capital) e vigilância de fatores de risco e proteção para doenças crônicas por inquérito telefônico (VIGITEL - São Paulo)}

\author{
Neuber José Segri' \\ Priscila Maria S. Bergamo Francisco" \\ Maria Cecília Goi Porto Alves"' \\ Marilisa Berti de Azevedo Barros" \\ Chester Luiz Galvão Cesar' \\ Moisés Goldbaum ${ }^{\prime v}$ \\ Deborah Carvalho Malta ${ }^{\mathrm{v}, \mathrm{VI}}$
}

'Department of Epidemiology of the School of Public Health at Universidade de São Paulo (USP) - São Paulo (SP), Brazil

"Departament of Social and Preventive Medicine of Faculdade de Ciências Médicas at Universidade Estadual de Campinas (UNICAMP) - Campinas (SP), Brazil

"'Institute of Health - Secretariat of Health -São Paulo (SP), Brazil

IV Departament of Preventive Medicine of the School of Medicine at Universidade de São Paulo (USP) - São Paulo (SP), Brazil

${ }^{v}$ Coordination of Non-Communicable Diseases and Conditions - Secretariat of Health Surveillance - Ministry of Health - Brasília (DF), Brazil

V'Departament of Maternity Nursing and Public Health of the Nursing School at Universidade Federal de Minas Gerais (UFMG) - Belo Horizonte (MG), Brazil

Financial Support: Health Secretariat of São Paulo, by means of an accord with the Center of Support to the School of Public Health (FSP/USP) and support by Research and Projects Financing (FINEP).

Correspondence to: Department of Epidemiology of the School of Public Health at Universidade de São Paulo (USP) - Av. Dr. Arnaldo, 715. Bairro: Cerqueira Cesar,- CEP: 01246-904 - São Paulo (SP) - Brazil - Email: neuber@usp.br.

Conflict of interest: nothing to declare.

\section{Abstract}

Objective: The aim of this study was to compare estimates of Pap smear and mammogram screening obtained from household and telephone surveys in women living in São Paulo in 2008, according to sociodemographic characteristics, and to measure the differences observed from those estimates. Methods: The study compared data from ISA - Capital 2008, a household survey conducted in São Paulo by Universidade de São Paulo (USP), Universidade Estadual de Campinas (UNICAMP) and the State Health Department with support from the Municipal Health Department, and VIGITEL - São Paulo, a telephone-based Surveillance of Risk and Protective Factors for Chronic Diseases. Estimates of Pap smear and mammography, as well as their realization in the year prior to the interview, were compared according to type of survey (household/telephone) by Poisson regression adjusted for age and education. Results: There were no statistically significant differences between the estimates obtained by VIGITEL and ISA - Capital as to the prevalence of mammography in the year prior to the interview. However, global estimates of the Pap smear at least once in life and in the past year, as well as mammograghy at least once in life, shown statistically significant differences, with higher prevalence rates of coverage among those interviewed by telephone. Conclusion: The results indicate a tendency to overestimate coverage of mammography and Pap smear in the telephone survey data, which indicates the need for new studies that also contribute to a better understanding of the differences observed by different types of surveys.

Keywords: health surveys; prevalence; cervix uteri; mammography; Brazil; interview; telephone. 


\section{Resumo}

Objetivo: $\mathrm{O}$ objetivo deste estudo foi comparar estimativas obtidas em inquéritos domiciliar e telefônico, da realização dos exames de Papanicolaou e mamografia em mulheres residentes no município de São Paulo em 2008, segundo características sociodemográficas, bem como dimensionar as diferenças observadas. Métodos: Foram utilizados os dados do ISA - Capital 2008, inquérito domiciliar realizado no município de São Paulo pela Universidade de São Paulo (USP), Universidade Estadual de Campinas (UNICAMP) e Secretaria de Estado da Saúde com apoio da Secretaria Municipal de Saúde de São Paulo, e do VIGITEL - São Paulo, inquérito telefônico realizado pelo Ministério da Saúde para Vigilância de Fatores de Risco e Proteção para Doenças Crônicas. Estimativas da realização do exame de Papanicolaou e mamografia na vida, bem como a realização no último ano foram comparadas segundo o tipo de inquérito (domiciliar/telefone) por meio de regressão de Poisson ajustada por idade e escolaridade. Resultados: Não foram encontradas diferenças estatisticamente significantes entre as estimativas obtidas pelo VIGITEL e ISA - Capital para as prevalências de realização de mamografia no último ano. No entanto, para as estimativas globais de realização do exame de Papanicolaou alguma vez na vida e no último ano e da mamografia na vida, foi possível verificar diferenças estatisticamente significantes, com prevalências de cobertura superiores entre as entrevistadas pelo inquérito telefônico. Conclusão: Os resultados sinalizam a tendência de superestimação de alguns indicadores de cobertura de mamografia e de exame de Papanicolaou nos dados de pesquisa via telefone, apontando a necessidade de novos estudos que também contribuam para o melhor entendimento das diferenças observadas com o uso de diferentes modalidades de inquéritos.

Palavras-chave: inquéritos epidemiológicos; prevalência; colo do útero; mamografia; Brasil; entrevista; telefone.

\section{Introduction}

Breast cancer and uterine cervical neoplasm present high rates of incidence and mortality. Depending on the stage, both are prone to early detection and cure $^{1-3}$. Among the preventive practices recommended for breast cancer screening, mammography enables the identification of subclinical lesions ${ }^{1,2}$. As to uterine cervical neoplasm, the Pap smear is considered efficient for the early detection ${ }^{3,4}$.

According to Viacava, Souza-Junior and Moreira ${ }^{5}$, estimates on the coverage of mammography obtained by household surveys have been used to monitor actions related to early detection of breast cancer in many countries, to assess the effect of the increased coverage in the reduction of mortality and the increase of survival rates. In Brazil, data from different population surveys have been used to estimate the coverage of mammography and Pap smear $^{5-9}$.

Population-based surveysarecommonly used in epidemiological research and represent one of the most traditional study designs to obtain information on different dimensions related to the health-disease process. They are also essential to monitor the prevalence of health problems and the magnitude of social inequalities in health as to the study of access and use of medical care $^{10,11}$.

In countries with wide telephone coverage, telephone surveys are common $^{12-15}$. In Brazil, a pilot system of telephone survey was successfully established in São Paulo to analyze risk factors for chronic non-communicable diseases in $2003^{16}$. In 2006, the Ministry of Health adopted the system, which was distributed to all Brazilian capitals and the Federal District ${ }^{17}$.

Due to the recent use of this type of survey in the health field, it is necessary to compare its estimates with those obtained by household surveys, which are more traditional ${ }^{14,18}$, in order to study its validity 
and information bias. The importance of comparison is reinforced by the advantages presented by telephone surveys, which are low cost and speed ${ }^{16,19}$, enabling the periodic collection of information to monitor risk factors in the population.

The objective of this studywas to compare estimates of Pap smear and mammogram screening obtained from household survey (ISA-Capital) and telephone survey (VIGITEL) in women living in São Paulo in 2008, according to sociodemographic characteristics, and to measure the differences observed from those estimates.

\section{Methods}

In order to compare prevalence estimates of preventive tests, data from two types of health surveys were used: a household (ISA - Capital 2008) and a telephone survey (VIGITEL - São Paulo 2008).

\section{ISA - Capital 2008}

The health survey in the city of São Paulo (ISA - Capital 2008) is a cross-sectional population-based study that was conducted in 2008 with the objective of analyzing life and health conditions, including the access to medical care, by means of household interviews.

Since 2002, the same group of researchers that are responsible for ISA - Capital2008 has been performing household health surveys in areas of the State of São Paulo, including its capital. The first one, ISA-SP ${ }^{20}$, consisted of 6,819 interviews with people in two cities of the state (Botucatu and Campinas) and in two areas of the metropolitan region of São Paulo (the first one comprises the cities of Taboão da Serra, Embu and Itapecerica da Serra, and the second one is compounded by the districts Vila Sônia, Morumbi, Rio Pequeno, Raposo Tavares, Jaguaré e Butantã). In the following year, for ISA Capital 2003, 3,357 people were interviewed to compose the probability sample of the city of São Paulo.
After 5 years, ISA - Capital 2008 interviewed 3,271 people of all ages, living in the urban area of the city, with the objective to analyze life and health conditions of the population, as well as possible changes that might have happened in the period.

Considering a two-stage cluster sampling, which the first one comprised of census tracts (70) and the second one of households $(2,249)$, the residents were drawn to compound the sample of 8 demographic domains (individuals aged less than one year; 1 to 11 years; 12 to 19 years, males and females; 20 to 59 years, males and females; 60 years or older, males and females). The sample of the smaller group (younger than 1 year old) consisted of 300 children, based on an estimated proportion of $50 \%$ ( $\mathrm{p}=0.50), 95 \%$ confidence level $(\mathrm{z}=196)$, sampling error of $7 \%$ and design effect of $1.5(\mathrm{deff}=1.5)^{21,22}$.

Data from the participants were obtained by a questionnaire structured into themes, according to life conditions, lifestyles, health status, as well as access and use of health services. These questionnaires were given by the interviewers, and directly answered by the residents. After data-collection, questionnaires were double-typed in the Epidata software; afterwards data went through a validation and consistence process for the establishment of the final databank, performed with the software Stata 10.0.

Sampling weights were calculated for each individual considering the aspects of the sample design, the adjustment for non-response related to census tracts according to the percentage of heads of families with a graduation degree in three levels (less than $5 \%$ of them had a graduation degree; 5 to $25 \%$; more than $25 \%$ ), and post-stratification adjustment, according to data from PNAD 2008 as to gender (male and female) and age groups ( 0 to 11 years; 12 to 19 years; 20 to 39 years; 40 to 59 years; 60 years or more), in order to equalize the sociodemographic features of the sample and those of the city of São Paulo in the analyzed year. 
The telephone-based Surveillance of Risk and Protective Factors for Chronic Diseases (VIGITEL) is a monitoring system established by the Ministry of Health and, since 2006, it has interviewed more than 54,000 people a year in the 26 Brazilian capitals and the Federal District by means of telephone landline interviews.

A probability sample of the population aged 18 years or older was performed in two stages: drawing of telephone lines and afterward selection of one resident in the household to be interviewed. In 2008, a total of 2,013 individuals were interviewed in the city of São Paulo, which enables to estimate the prevalence of risk factors for chronic non-communicable diseases with a $95 \%$ confidence coefficient and a maximum error of 2 percentage points ${ }^{17}$.

To obtain information by telephone, a computer was used to immediately read and register the responses of the participants. This questionnaire was comprised of questions regarding demographic and socioeconomic characteristics of the individuals, as well as information on health status, preventive practices, eating habits and physical activity associated with chronic non-communicable diseases ${ }^{17}$.

Sampling weights are attributed to each individual interviewed by VIGITEL in order to compensate for the different selection probabilities and to decrease bias resulting from non-response and the lack of universal telephone line coverage. The weight is a result of the multiplication of three factors. The first one considers the number of telephone lines in the selected household; the other is related to the number of adults in the household; and the last is a poststratification factor calculated based on data from Census 2000, considering 36 sociodemographic strata resulting from the combination of two categories of gender, six categories of age (18-24, 25-34, 35-44, 45-54, $55-64$ and 65 years or older) and three levels of schooling (0-8, 9-11, 12 years of schooling or more $)^{17,23}$.

\section{Comparison of survey estimates}

In this study, 2,443 non-institutionalized women aged 20 years or more, living in the urban area of the city of São Paulo in 2008 were considered; 1,238 were interviewed by ISA - Capital and 1,205 by VIGITEL - São Paulo.

At first, the population was characterized as to age (in years), marital status (single, married or with a partner, widower, separated or divorced), schooling, considering full years of study ( 0 to 8,9 to 11,12 years or more) and skin color/ethnicity (white and non-white); indigenous women were included in the non-white category.

Afterwards, prevalence estimates of Pap smear and mammogram screening, as well as the time in relation to the last doctor appointment, were obtained and compared as to the type of survey (household/ telephone).

It is important to emphasize that information from both surveys were gathered in one databank, according to Lee et $\mathrm{al}^{18}$, who recommends this combination must be performed in a way that all variables have the same name and the same response categories, and that a new variable must be created to identify from which bank (survey) the observation comes from (Chart 1).

Estimates related to sociodemographic characteristics of both surveys were compared by the Student's t-test for independent samples. Prevalence rates of preventive tests were compared by Poisson regression so that the dependent variable would be the characteristic of interest (prevalence of examinations and time in relation to the last appointment), and the independent variable would be the one to identify the type of survey (household/ telephone). Thus, if this independent variable were statistically significant, there would be enough evidence to assume the existence of differences between the two types of surveys, considering a $\mathrm{p}$-value of 0.05 for the Wald test.

Because the post-stratification weights of the surveys were calculated based on 
different years, which led to different sampling distributions by age and schooling, these variables were included as adjustment in order to obtain prevalence ratio estimates.

The software Stata 10.0 was used to analyze these data because it allows the inclusion of different features of the sampling complex design, present in both types of surveys (sampling weights and primary sampling units) ${ }^{21,24}$.

The project to establish VIGITEL was approved by the Human Research Ethics Committee of the Ministry of Health, and the research project ISA - São Paulo was approved by the Research Ethics Committee of the School of Public Health at Universidade de São Paulo, protocol n. 381 (protocol 13/01).

\section{Results}

The estimated mean age of women living in the city of São Paulo according to ISA - Capital was 43.9 years $(95 \% \mathrm{CI} ; 42.5$ - 45.2), and 41.9 years (95\%CI; 40.7 - 43.0) according to VIGITEL - São Paulo, which is significantly lower $(\mathrm{p}=0.0026)$.

The percentage distribution of women as to marital status, skin color/ethnicity and

Chart 1. Variables of ISA - Capital 2008 survey, VIGITEL 2008 survey used in combined data bank. São Paulo, 2010 Quadro 1. Variáveis dos inquéritos ISA - Capital 2008, VIGITEL 2008 e utilizadas para a união dos bancos de dados. São Paulo, 2010

\begin{tabular}{|c|c|c|}
\hline $\begin{array}{l}\text { ISA - Capital } 2008 \\
\mathrm{n}=1,238\end{array}$ & $\begin{array}{l}\text { VIGITEL - SP } 2008 \\
n=1,205\end{array}$ & $\begin{array}{l}\text { Unique databank } \\
n=2,443\end{array}$ \\
\hline $\begin{array}{l}\text { Age (years) } \\
\text { _ years old }\end{array}$ & $\begin{array}{l}\text { How old are you (years) } \\
\text { _ years old }\end{array}$ & $\begin{array}{l}\text { Age (years) } \\
\text { - Quantitative variable }\end{array}$ \\
\hline $\begin{array}{l}\text { What is your marital status? } \\
\text { Married } \\
\text { Stable union } \\
\text { Single } \\
\text { Separated } \\
\text { Divorced } \\
\text { Widow }\end{array}$ & $\begin{array}{l}\text { What is your current marital status? } \\
\text { Single } \\
\text { Married/with a partner } \\
\text { Widow } \\
\text { Separated/divorced }\end{array}$ & $\begin{array}{l}\text { Marital status } \\
\text { (4 categories) } \\
\text {-Single } \\
\text {-Married+With a partner } \\
\text {-Separated+Divorced } \\
\text {-Widow }\end{array}$ \\
\hline $\begin{array}{l}\text { Until which grade did you go to } \\
\text { school? } \\
\text { Never/cannot read and write } \\
\text { Never/can read and write } \\
\text { Primary school } \\
\text { Secondary school } \\
\text { Technical secondary school } \\
\text { Incomplete superior education } \\
\text { Complete superior education } \\
\text { Do not know } \\
\text { Did not answer }\end{array}$ & $\begin{array}{l}\text { Until which grade did you study? } \\
\text { Primary school } \\
\text { Admission } \\
\text { Primary school } \\
\text { Secondary school or technical or } \\
\text { normal or scientific secondary school } \\
\text { Superior education } \\
\text { post-graduation (specialization, } \\
\text { masters, doctorate) } \\
\text { Never studied } \\
\text { Do not know }\end{array}$ & $\begin{array}{l}\text { Schooling } \\
\text { ( } 3 \text { categories) } \\
-0 \text { to } 8 \text { years } \\
-9 \text { to } 11 \text { years } \\
-12 \text { years or more }\end{array}$ \\
\hline $\begin{array}{l}\text { What is your color or ethnicity? } \\
\text { White } \\
\text { Black } \\
\text { Brown } \\
\text { Yellow } \\
\text { Indigenous } \\
\text { Do not know/Did not answer }\end{array}$ & $\begin{array}{l}\text { Your skin color is: } \\
\text { White } \\
\text { Black } \\
\text { Brown or dark } \\
\text { Yellow (east descendency) } \\
\text { Red (indigenous descendency) } \\
\text { Do not know } \\
\text { Did not want to inform }\end{array}$ & $\begin{array}{l}\text { Race } \\
\text { ( } 2 \text { categories) } \\
\text {-White } \\
\text {-Non-white }\end{array}$ \\
\hline
\end{tabular}


Chart 1. continuation

Quadro 1. continuação

\begin{tabular}{|c|c|c|}
\hline $\begin{array}{l}\text { The Pap smear is used in programs } \\
\text { to prevent against uterine cervical } \\
\text { neoplasm. Have you ever had this } \\
\text { examination? } \\
\text { No } \\
\text { Yes } \\
\text { Do not know/Did now answer } \\
\text { When was the last time? } \\
\text { Less than one year ago } \\
\text { From } 1 \text { to } 2 \text { incomplete years } \\
\text { From } 2 \text { to } 3 \text { incomplete years } \\
\text { More than } 3 \text { years ago } \\
\text { Do not know/Did not answer }\end{array}$ & $\begin{array}{l}\text { Have you ever had a Pap smear? } \\
\text { (only for females) } \\
\text { Yes } \\
\text { No } \\
\text { Do not know } \\
\text { How long has it been since you had } \\
\text { a Pap smear? } \\
\text { Less than one year } \\
\text { From } 1 \text { to } 2 \text { years } \\
\text { From } 2 \text { to } 3 \text { years } \\
\text { From } 3 \text { to } 5 \text { years } \\
5 \text { years or more } \\
\text { Do not remember }\end{array}$ & $\begin{array}{l}\text { Pap smear } \\
\text { ( } 2 \text { categories) } \\
\text {-Yes } \\
\text {-No } \\
\text { Last Pap smear } \\
\text { (2 categories) } \\
\text {-Less than one year } \\
\text {-One year or more }\end{array}$ \\
\hline $\begin{array}{l}\text { Mammography is a breast x-ray used } \\
\text { in programs to prevent against breast } \\
\text { cancer. When was the last time you had } \\
\text { this examination? } \\
\text { Never } \\
\text { Less than one year ago } \\
1 \text { or } 2 \text { incomplete years ago } \\
2 \text { or } 3 \text { incomplete years ago } \\
3 \text { years ago } \\
\text { Do not know/Did not answer }\end{array}$ & $\begin{array}{l}\text { Have you ever had a mammo- } \\
\text { graphy, breast x-ray? } \\
\text { (only for females) } \\
\text { Yes } \\
\text { No } \\
\text { Do not know } \\
\text { How long has it been since you had } \\
\text { a mammography? } \\
\text { Less than } 1 \text { year } \\
\text { From } 1 \text { to } 2 \text { years } \\
\text { From } 2 \text { to } 3 \text { years } \\
\text { From } 3 \text { to } 5 \text { years } \\
5 \text { years or more } \\
\text { Do not remember }\end{array}$ & $\begin{array}{l}\text { Mammography } \\
\text { ( } 2 \text { categories) } \\
\text {-Yes } \\
\text {-No } \\
\text { Last mammography } \\
\text { ( } 2 \text { categories) } \\
\text {-Less than } 1 \text { year } \\
-1 \text { year or more }\end{array}$ \\
\hline
\end{tabular}

schooling according to both types of survey are demonstrated in table 1 . In relation to marital status, most women are married/ with a partner in both surveys, and only this category did not present a statistically significant difference $(\mathrm{p}=0.725)$. According to VIGITEL, there is a higher percentage of single women in relation to ISA - Capital $(\mathrm{p}=0.006)$, and a lower percentage of separated/divorced women $(\mathrm{p}=0.036)$ and widowers $(\mathrm{p}=0.029)$.

In relation to skin color/ethnicity, $64.2 \%$ reported being White, according to the household survey; this percentage was lower in the telephone survey $(\mathrm{p}<0.001)$.
As to schooling, the only statistically significant difference between surveys was in the category 0 to 8 years of schooling $(p=0.019)$.

The prevalence of Pap smear for women aged 20 years or more, according to ISA Capital, was $90.3 \%$; meanwhile, for VIGITEL this prevalence was about $4 \%$ higher (which is expressed by the prevalence ratio of 1.04 , adjusted by age and schooling), reaching 93.5\%. Likewise, according to VIGITEL, a higher percentage of women had this examination in the year prior to the interview $(\mathrm{p}=0.016), \quad$ regardless of differences concerning age and schooling observed in the surveys (Table 2). 
By analyzing the coverage of mammography for women aged 40 years or more, the prevalence found by VIGITEL was about $7 \%$ higher (87.4\% versus $82.0 \%)$. However, in relation to those who had this examination in the year prior to the interview, no statistically significant difference was found between estimates from both surveys ( $\mathrm{p}=0.231)$.

Tables 3 and 4 demonstrate the prevalence of these examinations according to sociodemographic characteristics of both analyzed surveys. VIGITEL found a higher prevalence of Pap smear (Table 3) for 20 to

Table 1. Frequency distribution of female adult population (aged 20 years and older), according to sociodemographic characteristics. ISA - Capital 2008 and VIGITEL - SP 2008

Tabela 1. Distribuição percentual da população adulta feminina (20 anos ou mais), segundo características sociodemográficas. ISA - Capital 2008 e VIGITEL - SP 2008

\begin{tabular}{lcccc}
\hline Variables and categories & \multicolumn{2}{c}{ ISA - Capital } & \multicolumn{2}{c}{ VIGITEL - SP } \\
\cline { 2 - 5 } & $\mathrm{n}$ & $(\%)^{*}(95 \% \mathrm{Cl})$ & $\mathrm{n}$ & $(\%)^{*}(95 \% \mathrm{Cl})$ \\
\hline Marital status & & & & \\
$\quad$ Single & 229 & $24.5(21.3-27.7)$ & 331 & $31.4(27.7-35.0)$ \\
$\quad$ Married/with a partner & 597 & $54.1(50.4-57.7)$ & 593 & $53.1(49.4-56.8)$ \\
$\quad$ Widower & 279 & $10.9(9.1-12.8)$ & 161 & $8.3(6.8-9.9)$ \\
$\quad$ Separated/divorced & 133 & $10.5(8.2-12.8)$ & 120 & $7.2(5.3-9.1)$ \\
Ethnicity & & & & \\
$\quad$ White & 795 & $64.2(58.9-69.5)$ & 665 & $49.1(45.4-52.8)$ \\
$\quad$ Non-white & 441 & $35.8(30.5-41.1)$ & 540 & $50.9(47.2-54.6)$ \\
Schooling & & & & \\
$\quad$ to 8 years & 628 & $30.9(26.4-35.4)$ & 356 & $38.0(34.2-41.8)$ \\
$\quad$ to 11 years & 441 & $46.0(42.4-49.6)$ & 517 & $43.8(40.0-47.5)$ \\
$\quad 12$ years or more & 167 & $23.1(17.6-28.5)$ & 320 & $18.3(16.0-20.5)$ \\
\hline
\end{tabular}

*weighted percentage

*Porcentagem da amostra ponderada

Table 2. Prevalence of preventive practices of female adult population. ISA - Capital 2008 and VIGITEL - SP, 2008

Tabela 2. Prevalência de práticas preventivas das mulheres adultas e tempo da realização. ISA - Capital 2008 e VIGITEL - SP 2008

\begin{tabular}{|c|c|c|c|c|c|c|c|}
\hline \multirow{2}{*}{$\begin{array}{l}\text { Variables and } \\
\text { Categories }\end{array}$} & \multicolumn{2}{|c|}{ ISA - Capital } & \multicolumn{2}{|c|}{ VIGITEL - SP } & \multicolumn{2}{|c|}{$\begin{array}{c}\text { Adjusted } \\
\text { Prevalence ratio * }\end{array}$} & \multirow{2}{*}{$p$-value ${ }^{* *}$} \\
\hline & $\mathrm{n}$ & $\begin{array}{l}\text { Prevalence } \\
(95 \% \mathrm{Cl})\end{array}$ & $\mathrm{n}$ & $\begin{array}{l}\text { Prevalence } \\
(95 \% \mathrm{Cl})\end{array}$ & & $(95 \% \mathrm{Cl})$ & \\
\hline Pap smear ${ }^{1}$ & 1,237 & - & 1,205 & - & - & - & - \\
\hline Ever had & 1,121 & $90.3(88.3-92.4)$ & 1,131 & $93.5(91.8-95.2)$ & 1.04 & $(1.01-1.07)$ & 0.016 \\
\hline Had in past year & 540 & $54.1(49.0-59.2)$ & 707 & $62.1(58.4-65.9)$ & 1.14 & $(1.03-1.28)$ & 0.016 \\
\hline Mammogram² & 864 & - & 753 & - & - & - & - \\
\hline Ever had & 701 & $82.0(78.8-85.3)$ & 669 & $87.4(84.4-90.4)$ & 1.07 & $(1.02-1.13)$ & 0.005 \\
\hline Had in past year & 341 & $54.0(49.5-58.5)$ & 400 & $59.1(54.6-63.7)$ & 1.07 & $(0.96-1.20)$ & 0.231 \\
\hline
\end{tabular}


39 year-old $(\mathrm{p}=0.030)$, single $(\mathrm{p}=0.001)$, and non-white $(\mathrm{p}=0.022)$ women in relation to ISA - Capital. As to having the examination in the past year, VIGITEL estimates are higher for the 40 to 59 year-old ( $\mathrm{p}=0.021)$, widower $(\mathrm{p}=0.003)$, white women $(\mathrm{p}=0.010)$ with fewer years of schooling ( $\mathrm{p}=0.043)$.

The prevalence estimates as to mammography are higher according to
VIGITEL than to ISA - Capital for the 40 to 59 year-old $(\mathrm{p}=0.008)$, widower $(\mathrm{p}=0.034)$, white women $(\mathrm{p}=0.016)$ with fewer years of schooling $(\mathrm{p}=0.019)$. In relation to having a mammography in the past year, VIGITEL estimates were $20 \%$ higher only for women with 0 to 8 years of schooling $(\mathrm{p}=0.045)$. However, there were no statistically significant differences for the other variables in

Table 3. Prevalence of Pap smear and last visit, according to age, marital status, ethnicity and schooling. ISA - Capital 2008 and VIGITEL - SP 2008

Tabela 3. Prevalência da realização do exame de Papanicolaou e tempo da última consulta, segundo faixa etária, situação conjugal, raça e escolaridade. ISA - Capital, 2008 e VIGITEL-SP, 2008

\begin{tabular}{|c|c|c|c|c|c|c|}
\hline \multirow{2}{*}{ Variables and categories } & \multicolumn{3}{|c|}{ Pap smear } & \multicolumn{3}{|c|}{ Performance in the past year } \\
\hline & ISA - Capital & VIGITEL & PR (Adjusted*) & ISA - Capital & VIGITEL & PR (Adjusted*) \\
\hline \multicolumn{7}{|l|}{ Age group ${ }^{* *}$} \\
\hline 20 to 39 & $\begin{array}{c}84.6 \\
(80.1-89.1)\end{array}$ & $\begin{array}{c}91.6 \\
(88.8-94.3)\end{array}$ & $\begin{array}{c}1.07 \\
(1.01-1.14)\end{array}$ & $\begin{array}{c}59.9 \\
(52.4-67.4)\end{array}$ & $\begin{array}{c}65.2 \\
(59.1-71.4)\end{array}$ & $\begin{array}{c}1.12 \\
(0.96-1.30)\end{array}$ \\
\hline 40 to 59 & $\begin{array}{c}97.0 \\
(95.3-98.7)\end{array}$ & $\begin{array}{c}98.2 \\
(96.6-99.8)\end{array}$ & $\begin{array}{c}1.02 \\
(0.99-1.04)\end{array}$ & $\begin{array}{c}55.6 \\
(49.1-62.1)\end{array}$ & $\begin{array}{c}65.6 \\
(60.3-70.8)\end{array}$ & $\begin{array}{c}1.18 \\
(1.03-1.36)\end{array}$ \\
\hline 60 or more & $\begin{array}{c}91.4 \\
(89.1-93.6)\end{array}$ & $\begin{array}{c}89.6 \\
(85.0-94.2)\end{array}$ & $\begin{array}{c}0.99 \\
(0.93-1.04)\end{array}$ & $\begin{array}{c}37.5 \\
(32.8-42.1)\end{array}$ & $\begin{array}{c}43.4 \\
(36.3-50.4)\end{array}$ & $\begin{array}{c}1.17 \\
(0.95-1.44)\end{array}$ \\
\hline \multicolumn{7}{|l|}{ Marital status } \\
\hline Single & $\begin{array}{c}69.8 \\
(62.7-76.9)\end{array}$ & $\begin{array}{c}85.5 \\
(81.1-90.0)\end{array}$ & $\begin{array}{c}1.20 \\
(1.08-1.36)\end{array}$ & $\begin{array}{c}54.9 \\
(45.7-64.0)\end{array}$ & $\begin{array}{c}57.7 \\
(49.5-66.0)\end{array}$ & $\begin{array}{c}1.18 \\
(0.97-1.43)\end{array}$ \\
\hline Married/with a partner & $\begin{array}{c}97.9 \\
(96.8-99.1)\end{array}$ & $\begin{array}{c}98.1 \\
(96.7-99.5)\end{array}$ & $\begin{array}{c}1.00 \\
(0.98-1.02)\end{array}$ & $\begin{array}{c}58.4 \\
(52.3-64.5)\end{array}$ & $\begin{array}{c}65.7 \\
(61.1-70.3)\end{array}$ & $\begin{array}{c}1.12 \\
(0.99-1.27)\end{array}$ \\
\hline Widower & $\begin{array}{c}93.8 \\
(91.2-96.4)\end{array}$ & $\begin{array}{c}91.6 \\
(86.5-96.6)\end{array}$ & $\begin{array}{c}0.98 \\
(0.92-1.04)\end{array}$ & $\begin{array}{c}34.4 \\
(26.8-42.1)\end{array}$ & $\begin{array}{c}51.3 \\
(41.5-61.1)\end{array}$ & $\begin{array}{c}1.52 \\
(1.15-2.01)\end{array}$ \\
\hline Separated/divorced & $\begin{array}{c}95.4 \\
(92.2-98.6)\end{array}$ & $\begin{array}{c}96.7 \\
(92.4-100.0)\end{array}$ & $\begin{array}{c}1.02 \\
(0.97-1.08)\end{array}$ & $\begin{array}{c}50.2 \\
(40.9-59.5)\end{array}$ & $\begin{array}{c}63.6 \\
(51.4-75.8)\end{array}$ & $\begin{array}{c}1.25 \\
(0.97-1.61)\end{array}$ \\
\hline \multicolumn{7}{|l|}{ Ethnicity } \\
\hline White & $\begin{array}{c}92.5 \\
(90.2-94.7)\end{array}$ & $\begin{array}{c}94.2 \\
(92.0-96.4)\end{array}$ & $\begin{array}{c}1.02 \\
(0.98-1.06)\end{array}$ & $\begin{array}{c}53.3 \\
(47.4-59.1)\end{array}$ & $\begin{array}{c}64.0 \\
(59.0-69.0)\end{array}$ & $\begin{array}{c}1.19 \\
(1.04-1.35)\end{array}$ \\
\hline Non-white & $\begin{array}{c}86.5 \\
(81.9-91.0)\end{array}$ & $\begin{array}{c}92.8 \\
(90.3-95.4)\end{array}$ & $\begin{array}{c}1.07 \\
(1.01-1.13)\end{array}$ & $\begin{array}{c}55.7 \\
(47.9-63.4)\end{array}$ & $\begin{array}{c}60.3 \\
(54.8-65.9)\end{array}$ & $\begin{array}{c}1.09 \\
(0.93-1.28)\end{array}$ \\
\hline \multicolumn{7}{|l|}{ Schooling*** } \\
\hline 0 to 8 years & $\begin{array}{c}92.7 \\
(90.8-94.7)\end{array}$ & $\begin{array}{c}95.6 \\
(93.5-97.7)\end{array}$ & $\begin{array}{c}1.02 \\
(0.98-1.05)\end{array}$ & $\begin{array}{c}44.3 \\
(37.5-51.2)\end{array}$ & $\begin{array}{c}56.1 \\
(49.1-63.0)\end{array}$ & $\begin{array}{c}1.22 \\
(1.01-1.48)\end{array}$ \\
\hline 9 to 11 years & $\begin{array}{c}88.7 \\
(84.9-92.4)\end{array}$ & $\begin{array}{c}91.8 \\
(88.7-94.8)\end{array}$ & $\begin{array}{c}1.04 \\
(0.99-1.10)\end{array}$ & $\begin{array}{c}55.2 \\
(47.3-63.0)\end{array}$ & $\begin{array}{c}62.9 \\
(57.3-68.4)\end{array}$ & $\begin{array}{c}1.11 \\
(0.94-1.31)\end{array}$ \\
\hline 12 or more & $\begin{array}{c}90.7 \\
(85.7-95.7)\end{array}$ & $\begin{array}{c}93.6 \\
(90.3-96.9)\end{array}$ & $\begin{array}{c}1.03 \\
(0.97-1.10)\end{array}$ & $\begin{array}{c}65.6 \\
(57.0-74.2)\end{array}$ & $\begin{array}{c}73.3 \\
(67.9-78.7)\end{array}$ & $\begin{array}{c}1.12 \\
(0.96-1.30)\end{array}$ \\
\hline
\end{tabular}

PR - Prevalence ratio; *adjusted by age and schooling; **adjusted by schooling; ***adjusted by age

$P R$ - Razão de prevalência; *ajustada por idade e escolaridade; **ajustada apenas por escolaridade; ***ajustada apenas por idade 
both surveys (Table 4). It is important to emphasize that data were adjusted by age and schooling.

\section{Discussion}

This study compared estimates related to the coverage of Pap smear and mammography obtained by the self-report of the interviewee in household and telephone surveys. No statistically significant differences were found between estimates from VIGITEL and ISA - Capital for the prevalence of mammography in the past year.
However, global estimates related to having had a Pap smear or a mammography at least once or in the past year enabled the verification of statistically significant differences, with higher prevalence rates of coverage among those interviewed by the telephone survey.

Population-based surveys are important to produce information about health ${ }^{10}$, and the conduction of more studies on strategies adopted to collect data, such as by telephone, household, online and mail surveys, among other possibilities ${ }^{12}$, are essential.

Table 4. Prevalence of mammography and last visit, according to age, marital status, ethnicity and schooling. ISA Capital 2008 and VIGITEL - SP 2008

Tabela 4. Prevalência da realização de mamografia e tempo da última consulta, segundo faixa etária, situação conjugal, raça e escolaridade. ISA - Capital 2008 e VIGITEL - SP 2008

\begin{tabular}{|c|c|c|c|c|c|c|}
\hline \multirow{2}{*}{$\begin{array}{l}\text { Variables and } \\
\text { categories }\end{array}$} & \multicolumn{3}{|c|}{ Mammography } & \multicolumn{3}{|c|}{ Performance in the past year } \\
\hline & ISA - Capital & VIGITEL & PR (Adjusted*) & ISA - Capital & VIGITEL & PR (Adjusted*) \\
\hline \multicolumn{7}{|l|}{ Age group ${ }^{* *}$} \\
\hline 40 to 59 & $\begin{array}{c}81.8 \\
(77.8-85.9)\end{array}$ & $\begin{array}{c}88.4 \\
(84.6-92.2)\end{array}$ & $\begin{array}{c}1.09 \\
(1.02-1.16)\end{array}$ & $\begin{array}{c}58.6 \\
(52.4-64.7)\end{array}$ & $\begin{array}{c}64.4 \\
(59.0-69.9)\end{array}$ & $\begin{array}{c}1.10 \\
(0.96-1.26)\end{array}$ \\
\hline 60 or more & $\begin{array}{c}82.5 \\
(79.1-85.9)\end{array}$ & $\begin{array}{c}85.2 \\
(80.4-90.0)\end{array}$ & $\begin{array}{c}1.04 \\
(0.97-1.11)\end{array}$ & $\begin{array}{c}44.9 \\
(40.3-49.6)\end{array}$ & $\begin{array}{c}47.1 \\
(39.7-54.6)\end{array}$ & $\begin{array}{c}1.06 \\
(0.87-1.27)\end{array}$ \\
\hline \multicolumn{7}{|l|}{ Marital status } \\
\hline Single & $\begin{array}{c}78.4 \\
(67.9-88.8)\end{array}$ & $\begin{array}{c}77.9 \\
(68.6-87.3)\end{array}$ & $\begin{array}{c}1.06 \\
(0.91-1.24)\end{array}$ & $\begin{array}{c}46.6 \\
(33.0-60.2)\end{array}$ & $\begin{array}{c}55.2 \\
(43.0-67.5)\end{array}$ & $\begin{array}{c}1.20 \\
(0.84-1.73)\end{array}$ \\
\hline $\begin{array}{l}\text { Married/with a } \\
\text { partner }\end{array}$ & $\begin{array}{c}86.0 \\
(82.2-89.7)\end{array}$ & $\begin{array}{c}90.2 \\
(86.4-94.0)\end{array}$ & $\begin{array}{c}1.06 \\
(1.00-1.12)\end{array}$ & $\begin{array}{c}61.0 \\
(54.7-67.3)\end{array}$ & $\begin{array}{c}62.5 \\
(56.5-68.6)\end{array}$ & $\begin{array}{c}1.00 \\
(0.87-1.15)\end{array}$ \\
\hline Widower & $\begin{array}{c}75.1 \\
(68.0-82.1)\end{array}$ & $\begin{array}{c}85.4 \\
(79.2-91.6)\end{array}$ & $\begin{array}{c}1.14 \\
(1.01-1.28)\end{array}$ & $\begin{array}{c}40.0 \\
(32.4-47.5)\end{array}$ & $\begin{array}{c}53.8 \\
(43.6-64.1)\end{array}$ & $\begin{array}{c}1.29 \\
(1.00-1.68)\end{array}$ \\
\hline $\begin{array}{l}\text { Separated/ } \\
\text { divorced }\end{array}$ & $\begin{array}{c}78.7 \\
(69.2-88.3)\end{array}$ & $\begin{array}{c}89.3 \\
(80.3-98.2)\end{array}$ & $\begin{array}{c}1.14 \\
(0.98-1.33)\end{array}$ & $\begin{array}{c}47.8 \\
(34.8-60.7)\end{array}$ & $\begin{array}{c}52.7 \\
(40.7-64.8)\end{array}$ & $\begin{array}{c}1.12 \\
(0.78-1.60)\end{array}$ \\
\hline \multicolumn{7}{|l|}{ Ethnicity } \\
\hline White & $\begin{array}{c}83.6 \\
(80.0-87.2)\end{array}$ & $\begin{array}{c}87.4 \\
(83.2-91.6)\end{array}$ & $\begin{array}{c}1.05 \\
(0.98-1.12)\end{array}$ & $\begin{array}{c}53.1 \\
(47.4-58.7)\end{array}$ & $\begin{array}{c}62.1 \\
(56.1-68.1)\end{array}$ & $\begin{array}{c}1.14 \\
(0.99-1.31)\end{array}$ \\
\hline Non-white & $\begin{array}{c}78.5 \\
(71.7-85.2)\end{array}$ & $\begin{array}{c}87.4 \\
(83.0-91.7)\end{array}$ & $\begin{array}{c}1.13 \\
(1.02-1.24)\end{array}$ & $\begin{array}{c}56.3 \\
(48.2-64.4)\end{array}$ & $\begin{array}{c}55.9 \\
(49.1-62.7)\end{array}$ & $\begin{array}{c}0.99 \\
(0.82-1.19)\end{array}$ \\
\hline \multicolumn{7}{|l|}{ Schooling*** } \\
\hline 0 to 8 years & $\begin{array}{c}76.7 \\
(71.4-81.9)\end{array}$ & $\begin{array}{c}84.6 \\
(79.7-89.4)\end{array}$ & $\begin{array}{c}1.11 \\
(1.02-1.21)\end{array}$ & $\begin{array}{c}45.7 \\
(39.6-51.8)\end{array}$ & $\begin{array}{c}58.1 \\
(51.1-65.0)\end{array}$ & $\begin{array}{c}1.20 \\
(1.00-1.43)\end{array}$ \\
\hline 9 to 11 years & $\begin{array}{c}81.7 \\
(76.4-87.0)\end{array}$ & $\begin{array}{c}88.8 \\
(84.1-93.5)\end{array}$ & $\begin{array}{c}1.09 \\
(0.99-1.18)\end{array}$ & $\begin{array}{c}58.1 \\
(50.2-66.0)\end{array}$ & $\begin{array}{c}56.0 \\
(48.2-63.7)\end{array}$ & $\begin{array}{c}0.95 \\
(0.79-1.15)\end{array}$ \\
\hline 12 or more & $\begin{array}{c}96.1 \\
(92.1-100.0)\end{array}$ & $\begin{array}{c}93.7 \\
(89.8-97.7)\end{array}$ & $\begin{array}{c}0.98 \\
(0.92-1.04)\end{array}$ & $\begin{array}{c}62.7 \\
(52.8-72.6)\end{array}$ & $\begin{array}{c}68.9 \\
(60.7-77.2)\end{array}$ & $\begin{array}{c}1.09 \\
(0.89-1.34)\end{array}$ \\
\hline
\end{tabular}

PR - Prevalence Ratio; *adjusted by age and schooling; **adjusted by schooling; ***adjusted by age

$P R-$ Razão de Prevalência; *ajustada por idade e escolaridade; **ajustada apenas por escolaridade; ***ajustada apenas por idade 
The international experience in the comparison of different methodologies is more documented ${ }^{12,13,25}$ than in Brazil ${ }^{5}$. A study conducted in Madrid comparing telephone and face to face (household) surveys found similarity in 25 out of the 29 analyzed variables ${ }^{13}$. A study carried out in the United States comparing estimates obtained by telephone (Behavioral Risk Factor Surveillance System) and household (National Health Interview Survey) surveys showed similar data as to smoking, body weight, diabetes, arterial hypertension, immunization, health insurance coverage and cost as being limiting factors to health care ${ }^{12}$.

Davis et al. ${ }^{25}$ compared the prevalence of mammography considering telephone (BRFSS) and household (NHIS) NorthAmerican telephone surveys in the periods of 1997-1999 and 2000-2003 and, as in the present study, they observed that estimates originated by telephone were statistically higher than those originated by household surveys. The authors also pointed to the importance and suggested a model that could combine information and generate estimates coming from both types of surveys.

By comparing mammography estimates obtained by VIGITEL 2007 and those coming from the National Household Survey (PNAD - 2003) Viacava, Souza-Junior and Moreira ${ }^{5}$ observed that VIGITEL estimates were higher in all the analyzed capitals, with up to 9 percentage points of differences. Such differences were attributed to the fact that the population analyzed by the telephone survey has access to telephone lines and belongs to higher socioeconomic levels. By analyzing the post-stratification effect on the correction of data obtained by a subpopulation that had a residential telephone line in 2003 for the total population, Segri et al. ${ }^{23}$ observed that, in relation to mammography, the adjustment by gender, age and schooling was insufficient to properly adjust estimate bias.
The access to the Pap smear in the life of women aged 20 years or more in this study, despite the statistically significant difference between surveys, was higher than $90 \%$, and as to having had the exam in the year prior to the interview, higher than $50 \%$. Data from 2003 in the city of São Paulo showed similar values for the access throughout life (87.1\%) and in the previous year $(57.5 \%)$ for women in the same age groups ${ }^{23,26}$.

Another household study conducted in São Paulo in 2000 showed lower prevalence rates $(86.1 \%)$ of being examined at least once for women aged between 15 and 49 years; however, the coverage in the previous year was higher (65.5\%) for the same age group ${ }^{27}$. A household survey conducted in the city of Campinas in 2003 showed that the access to Pap smear was $83.3 \%$ for women aged 40 years or more ${ }^{9}$, and data from PNAD 2008 showed that in Brazil, the access to women aged 25 to 59 years reached $84.5 \%$, increasing to $90.0 \%$ in the Southeast region ${ }^{28}$.

In relation to the prevalence of mammography, the results in this study (regarding household and telephone surveys) were higher than $80 \%$, despite showing statistical differences. Results from a household survey conducted in the city of São Paulo in 2003 showed that the access to mammography for women aged 40 years or more was lower than $75 \%$; however, it was higher for women who owned a residential telephone line ${ }^{23}$.

Even with the broad telephone coverage in the city of São Paulo, the exclusion of those who do not own a telephone line in the sampling process of telephone surveys may lead to errors that are not paltry ${ }^{23,29,30}$. In relation to mammography, the weighting factors used to adjust the distribution of the sample of those who own a telephone line to the total population, according to sociodemographic characteristics associated with owning a residential telephone line, are not sufficient to reduce the acceptable level of bias associated with the produced estimates $^{23}$. 
A study conducted in Campinas with women aged 40 years or more showed lower prevalence rates as to the non-realization of mammography between those aged 70 years or more, who self-reported as being white or brown and who belonged to the lower per capita income stratum ${ }^{7}$. Likewise, data from PNAD 2008 showed that the access for women aged 50 to 69 years is higher than $70 \%$ in Brazil, reaching $81.9 \%$ in the Southeast region; however, fewer years of schooling and income are associated with the decreased access ${ }^{28}$. In relation to the Pap smear ${ }^{9}$, it was observed that factors that are independently associated with the non-realization of the exam were: being 40 to 59 years old, self-reporting color/ethnicity as brown or black, and having years of schooling equal or inferior to 4 years.

Results from a North-American study performed in 2006 by telephone (BRFSS) showed that the prevalence of mammography among women aged 40 years or more (60.8\%), as well as Pap smear (83.3\%) was lower to that described in this study, however, they also ranged according to ethnicity and socioeconomic level ${ }^{31}$.

The differences found in this study in relation to the mean age of women and schooling may result from the different structure of post-stratification adjustments used for the analyzed surveys. The fact that ISA - Capital uses data from 2008, while VIGITEL uses data from 2000 - when the population was younger and with fewer years of schooling - emphasizes the differences between these variables. In relation to the differences found as to marital status and especially color/ethnicity, the same observation may be considered. However, it is important to care for the differences among questions regarding these characteristics and some response categories of VIGITEL and ISA - Capital. As an example, there is the category "dark skin" in the former, but not in the latter.

Among the limitations in this study, the existence of differences in data collection instruments must be considered, as well as the response rates found in both survey types, which may interfere in the results ${ }^{11,12,14}$. As to the questionnaire, it is important to note that the question on the performance of examinations was not created the same way. For example, ISA Capital included information about the objective of the examinations in the title of the question. Besides, the size of the questionnaire and the order in which the questions were included are also different. Although it is not known if such aspects influence the estimated prevalence, it is not possible to rule out the hypothesis that they are partly responsible for the observed differences.

It is important to emphasize the importance of using statistical analysis techniques, especially Poisson regression models ${ }^{18}$, in data from both surveys gathered in one databank. This combination enabled the use of computational analysis modules which consider the different aspects of the complex sample plans, which differ in both surveys.

It is important to mention that the comparison between prevalence estimates was conducted by the prevalence ratio adjusted by age and schooling, once the surveys refer to populations with different percentage distributions as to these variables, because post-stratification adjustments at VIGITEL were made based on Census 2000, and ISA - Capital was based on PNAD 2008.

The results of this study indicate the tendency to overestimate some indicators of mammography and Pap smear coverage in the telephone survey data, which indicates the need for new studies that assess possible bias and its correction by post-stratification adjustments that contribute to a better understanding of the differences observed by different types of surveys. Thus, estimates obtained by telephone can continue to guide the planning of health promotion policies in the country. 


\section{References}

1. Robles SC, Galanis E. Breast cancer in Latin America and the Caribbean. Rev Panam Salud Publica. 2002;11:178-85.

2. Instituto Nacional de Câncer. Inquérito domiciliar sobre comportamento de risco e morbidade referida de doenças e agravos não transmissíveis. Brasil, 15 capitais e Distrito Federal, 2002-2003. Rio de Janeiro: Instituto Nacional do Câncer, 2004.

3. Gardner E. Cervical câncer: disparities in screening, treatment, and survival. Cancer Epidemiol Biomarkers Prev. 2003;12:242s-7s.

4. Fonseca LAM, Ramacciotti AS, Eluf Neto J. Tendência da mortalidade por câncer de útero no município de São Paulo entre 1980 e 1999. Cad Saúde Pública. 2004;20(1):136-42.

5. Viacava F, Souza-Junior PRB, Moreira RS. Estimativas da cobertura de mamografia segundo inquéritos de saúde no Brasil. Rev Saúde Pública. 2009;43 Suppl 2:117-125.

6. Lima-Costa MF, Matos DL. Prevalência e fatores associados à realização da mamografia na faixa etária de 50-69 anos: um estudo baseado na Pesquisa Nacional por Amostra de Domicílios (2003). Cad Saúde Pública. 2007;23(7):1665-73.

7. Amorim VMSL, Barros MBA, Cesar CLG, Carandina L, Goldbaum M. Fatores associados a não realização da mamografia e do exame clínico das mamas: um estudo de base populacional em Campinas, São Paulo, Brasil. Cad Saúde Pública. 2008;24(11):2623-32.

8. Dias-da-Costa JS, Olinto MTA, Gigante DP, Menezes AMB, Macedo S, Borba AT, et al. Cobertura do exame citopatológico na cidade de Pelotas, Rio Grande do Sul, Brasil. Cad Saúde Pública. 2003;19(1):191-7.

9. Amorim VMSL, Barros MBA, César CLG, Carandina L, Goldbaum M. Fatores associados à não realização do exame de Papanicolaou: um estudo de base populacional no Município de Campinas, São Paulo, Brasil. Cad Saúde Pública. 2006;22(11):2329-38.

10. Barros MBA. Inquéritos domiciliares de saúde: potencialidades e desafios. Rev Bras Epidemiol. 2008;11 Suppl 1: 6-19.

11. Waldman EA, Novaes MHD, Albuquerque MFM, Latorre MRDO; Ribeiro, MCSA; Vasconcellos M, et al. Inquéritos populacionais: aspectos metodológicos, operacionais e éticos. Rev Bras Epidemiol. 2008;11Suppl 1:168-79.

12. Nelson DE, Powell-Griner E, Town M, Kovar MG. A comparison of national estimates from the National Health Interview Survey and the Behavioral Risk Factor Surveillance System. Am J Public Health. 2003;93(8):1335-41.

13. Galán I, Rodríguez-Artalejo F, Tobías A, Gandarillas A, Zorrilla B. Vigilancia de los factores de riesgo de las enfermedades no transmisibles mediante encuesta telefónica: resultados de la Comunidad de Madrid en el período 1995-2003. Gac Sanit. 2005,19(3):193-205.

14. Fahimi M, Link M, Mokdad A, Schwartz DA, Levy P, Mokdad A. Tracking chronic disease and risk behavior prevalence as survey participation declines: statistics from the behavioral risk factor surveillance system and other national surveys. Prev Chronic Dis. 2008;5(3):A80.

15. Mokdad AH. The Behavioral Risk Factors Surveillance System: past, present, and future. Annu. Rev. Public Health. 2009;30:43-54.

16. Monteiro CA, Moura EC, Jaime PC, Lucca A, Florindo AA, Figueiredo ICR, et al. Monitoramento de fatores de risco para doenças crônicas por entrevistas telefônicas. Rev Saúde Pública. 2005;39(1):47-57.

17. Brasil. Ministério da Saúde. Secretaria de Vigilância em Saúde. Secretaria de Gestão Estratégia e Participativa. VIGITEL Brasil, 2008: vigilância de fatores de risco e proteção para doenças crônicas por inquérito telefônico. Brasília: Ministério da Saúde, 2009.

18. Lee S, Davis WW, Nguyen HA, McNeel TS, Brick JM, FloresCervantes I. Examining trends and averages using combined cross-sectional survey data from multiple years. CHIS Methodology Paper, 2007. [cited 2010 Set 19]. Available from: http://www.chis.ucla.edu/pdf/paper_trends_averages.pdf.

19. Lavrakas PJ. Telephone survey methods. Sampling, selection and supervision. London: Sage Publications, 1990.

20. Cesar CLG, Carandina L, Alves MCGP, Barros MBA, Goldbaum M. Saúde e condição de vida em São Paulo: inquérito multicêntrico de saúde no Estado de São Paulo (ISA - SP). São Paulo: USP/FSP; 2005.

21. Kish L. Survey sampling. New York: John Wiley and Sons; 1965.

22. Cesar CLG, Segri NJ, Sportello RA. Inquéritos de saúde no estado de São Paulo [internet]. São Paulo: Faculdade de Saúde Pública da USP; 2005. Disponível em: http://www. fsp.usp.br/isa-sp.

23. Segri NJ, Cesar CLG, Barros MBA, Alves MCGP, Carandina L, Goldbaum M. Inquérito de saúde: comparação dos entrevistados segundo posse de linha telefônica residencial. Rev. Saúde Pública. 2010;44(3):503-12.

24. Alves MCGP, Silva NN. Métodos de estimação de variância em amostras provenientes de inquéritos domiciliares. Rev. Saúde Pública. 2007;41(6):938-46.

25. Davis WW, Parsons VL, Xie D, Schenker N, Town M, Raghunatan TE, et al. State-based estimates of mammography screening rates based on information from two health surveys. Public Health Rep. 2010;125(4):567-578

26. Boletim CEInfo - ISA - Capital. Série: Destaques Temáticos, $\mathrm{n}^{\circ} 1,2006$. 
27. Pinho AA, França Junior I, Schraiber LB, D’Oliveira AFPL. Cobertura e motivos para a realização ou não do teste de Papanicolaou no Município de São Paulo. Cad. Saúde Pública. 2003;19 Suppl 2:S303-13.

28. Instituto Brasileiro de Geografia e Estatística - Pesquisa Nacional por Amostra de Domicilio. Um panorama da saúde no Brasil: acesso e utilização de serviços, condições de saúde e fatores de risco e proteção à saúde. Rio de Janeiro, 2010. [cited 2011 Jun 15]. Available from: http://www.ibge. gov.br/home/estatistica/populacao/panorama_saude_ brasil_2003_2008/PNAD_2008_saude.pdf.

29. Ford ES. Characteristics of survey participants with and without a telephone: findings from the third National Health and Nutrition Examination Survey. J Clinic Epidemiol. 1998;51(1):55-60.

30. Bernal R, Silva NN. Cobertura de linhas telefônicas residenciais e vícios potenciais em estudos epidemiológicos. Rev. Saúde Pública [online]. 2009, 43(3): 421-26.

31. Smith RA, Cokkinides V, Brawley OW. Cancer Screening in the United States, 2008: a review of current American Cancer Society guidelines and cancer screening issues. CA Cancer J Clin. 2008;58(3):161-179.

Submitted on: $05 / 01 / 2011$ Final version presented on: $23 / 02 / 2011$ Accepted on: 03/03/2011 